\title{
MOLECULAR IDENTIFICATION OF Aspergillus spp. ISOLATED FROM COFFEE BEANS
} \author{
Furlaneto ${ }^{4}$; Maria Helena Pelegrinelli Fungaro ${ }^{2 *}$ \\ ${ }^{1}$ UEL - Departamento de Bioquímica, C.P. 6001 - 86051-990 - Londrina, PR - Brasil. \\ ${ }^{2} U E L$ - Depto. de Biologia Geral. \\ ${ }^{3}$ UEL - Depto. de Agronomia. \\ ${ }^{4}$ UEL - Depto. de Microbiologia. \\ *Corresponding author $<$ fungaro@uel.br $>$
}

Marciane Magnani ${ }^{1}$; Thiago Fernandes ${ }^{2}$; Cássio Egidio Cavenaghi Prete ${ }^{3}$ Martin Homechim ${ }^{3}$; Elisabete Yurie Sataque $\mathrm{Ono}^{1}$; Laurival Antonio Vilas-Boas ${ }^{2}$; Daniele Sartori²; Márcia Cristina

\begin{abstract}
Some species belonging to the genus Aspergillus are potential producers of ochratoxin A (OA), a mycotoxin with nephrotoxic, immunosuppressive, teratogenic and carcinogenic effects. The aim of the present study was to identify the species of Aspergillus that contaminate the inside of coffee beans collected in the stage of maturation and drying, from 16 producing areas located in the northern region of the State of Paraná, in the South of Brazil. A total of 108 isolates of Aspergillus spp. was identified at the species level, by sequencing the internal transcribed spacer (ITS1-5.8S-ITS2) of ribosomal DNA (rDNA). The results revealed the presence of potentially ochratoxigenic species in $82 \%$ of the geographic regions studied, among which Aspergillus niger was the species most frequently detected, followed by $A$. ochraceus and $A$. carbonarius. The presence of $A$. carbonarius in immature coffee fruits harvested from trees is reported for the first time.
\end{abstract}

Key words: ITS, ribosomal DNA, ochratoxin, mycotoxin

\section{IDENTIFICAÇÃO MOLECULAR DE Aspergillus spp. ISOLADOS DE GRÃOS DE CAFÉ}

\begin{abstract}
RESUMO: Algumas espécies pertencentes ao gênero Aspergillus possuem potencial para produção de Ocratoxina A (OA), uma micotoxina de efeitos nefrotóxicos, imunossupressivos, teratogênicos e carcinogênicos. Com o objetivo de identificar as espécies de Aspergillus que contaminam o interior de grãos de café, foram coletadas amostras em diferentes estádios de maturação do produto, em 16 propriedades produtoras do norte do estado do Paraná. Um total de 108 isolados de Aspergillus spp. foram identificados ao nível de espécie, pelo sequenciamento dos espaços internos transcritos (ITS1-5,8S-ITS2) do DNA ribossomal (rDNA). Os resultados revelaram a presença de espécies potencialmente ocratoxigênicas em $82 \%$ das regiões analisadas, sendo dentre estas, Aspergillus niger a espécie mais freqüentemente detectada, seguida por $A$. ochraceus, e $A$. carbonarius. É relatada pela primeira vez a presença de $A$. carbonarius em frutos de café coletados na árvore.

Palavras-chave: ITS, DNA ribossomal, ocratoxina, micotoxina
\end{abstract}

\section{INTRODUCTION}

The ochratoxin $\mathrm{A}(\mathrm{OA})$ is the mycotoxin of greatest significance found in coffee beans and beverage. The presence of OA in coffee was first reported by Levi et al. (1974) followed by several other studies (Abarca et al., 1994; Moss 1996; Bucheli et al., 1998; Batista et al., 2003; Taniwaki et al., 2003).

The presence of this mycotoxin in food has been considered a worldwide problem in public health. In countries with tropical climates, species of Aspergillus have been the main ones responsible for the production of OA in coffee (Taniwaki et al., 2003). Based on this, studies aimed at identifying the species of Aspergillus that contaminate coffee and that are potential OA producers have become of great importance in the last decade.

The identification of fungal species by classic taxonomy is based mainly on the use of morphological markers. However, the number of these markers available is generally low, which makes difficult the classification and/or identification of related species. The development of molecular biology techniques for the genetic differentiation of species has resulted in substantial advances in taxonomy due to their sensitivity and specificity. The amplification of internal transcribed spacer (ITS1-5.8SITS2) of ribosomal DNA (rDNA) by the polymerase chain reaction (PCR) (Mullis \& Faloona, 1987), combined with sequencing of the amplicon and analysis of 
similarity between the sequences obtained and those already deposited in the gene bank, has been frequently employed for identification of fungal species. Despite this, no studies have been published using molecular approaches for the identification of Aspergillus spp. in coffee beans.

The aim of the present study was to isolate and identify, by sequencing of the ITS regions, Aspergillus spp. that contaminate the inside of coffee beans, produced in the northern region of the State of Parana, in the South of Brazil.

\section{MATERIAL AND METHODS}

Material - Samples of coffee (Coffea arabica) at different stages of maturation (immature fruits from trees, cherries from the drying yard and overripe cherries from soil) and from storage in barns were obtained from 16 coffee properties in northern region of state of Paraná, in the south region of Brazil. The sampling consisted of a random collection of $1 \mathrm{~kg}$ coffee beans. After external disinfecting of the beans with $1 \%$ solution of sodium hypochlorite, 200 beans were submitted to a Blotter test (Neergard, 1979) to expose the fungi. The differentiation of Aspergillus from other genera uncovered was conducted according to Pitt \& Hocking (1997). A total of 108 isolates of Aspergillus spp. were purified for molecular identification at the species level. These isolates were coded as indicated in Table 1.

Extraction of genomic DNA - Conidia of each isolate was inoculated in liquid medium (Pontecorvo et al., 1953) and incubated at $28^{\circ} \mathrm{C}$, for $24 \mathrm{~h}$, at $180 \mathrm{rpm}$. Genomic DNA was extracted according to Azevedo et al. (2000) and quantified by a fluorimetric method (Dyna Quant, Phamarcia).

PCR of ITS region - Fragments of the ITS1-5.8S-ITS2 were amplified by the use of the primers ITS 1 and ITS4 (White et al., 1990). The final volume of each reaction was $25 \mu \mathrm{L}$, containing $2.5 \mu \mathrm{L}$ of buffer $(200 \mathrm{mM}$ Tris$\mathrm{HCl}, \mathrm{pH} 8,4-500 \mathrm{mM} \mathrm{KCl}, 1 \mathrm{x}$ concentrated), $2.0 \mu \mathrm{L}$ of dNTPs $(2.5 \mathrm{mM}), 1.5 \mu \mathrm{L}$ of each of the primers ITS1 and ITS4 (Invitrogen - 10 pmol $\mu \mathrm{L}^{-1}$ ), $1.0 \mu \mathrm{L} \mathrm{MgCl}_{2}(50 \mathrm{mM}$ ), $0.2 \mu \mathrm{L}$ Taq DNA polymerase $\left(5 \mathrm{U}^{-1}\right), 2 \mu \mathrm{L}$ DNA (5 $\mathrm{ng} \mu \mathrm{L}^{-1}$ ) and $14.3 \mu \mathrm{L}$ of distilled water. The reaction mixture was placed in a PTC-100 thermocycler (MJ Research, Inc.) programmed to conduct 35 cycles after an initial denaturation of $4 \mathrm{~min}$ at $92^{\circ} \mathrm{C}$. Each amplification

Table 1 - Isolates of Aspergillus spp. from coffee beans sampled from different origins.

\begin{tabular}{|c|c|c|}
\hline Coffee sample & Maturation stage or storage & Coding of Aspergillus isolates \\
\hline 1 & storage & $\mathrm{A} 11, \mathrm{~A} 12, \mathrm{~A} 13$ \\
\hline 1 & drying yard & A21 \\
\hline 2 & storage & A51, A52 \\
\hline 2 & drying yard & A61, A62, A63, A64, A65 \\
\hline 2 & Immature fruits from tree & A71 \\
\hline 2 & cherries from soil & A 81 \\
\hline 3 & storage & A91, A92, A93 \\
\hline 3 & drying yard & $\mathrm{A} 101, \mathrm{~A} 102, \mathrm{~A} 103, \mathrm{~A} 104, \mathrm{~A} 105$ \\
\hline $4 \mathrm{~T}$ & storage & A 131, A 132 \\
\hline $4 \mathrm{~T}$ & drying yard & A 141 \\
\hline $4 \mathrm{~T}$ & Immature fruits from tree & A 151, A 152 \\
\hline $4 \mathrm{~T}$ & cherries from soil & A161, A162 \\
\hline 4 & storage & $4 \mathrm{~A}, 4 \mathrm{~B}, 4 \mathrm{C}, 4 \mathrm{D}, 4 \mathrm{~F}$ \\
\hline 6 & storage & $6 \mathrm{~A}$ \\
\hline 7 & storage & $7 \mathrm{~A}$ \\
\hline 8 & storage & $8 \mathrm{~A} 1,8 \mathrm{~A} 2,8 \mathrm{~B}$ \\
\hline 11 & storage & $11 \mathrm{~B}, 11 \mathrm{C}, 11 \mathrm{D}, 11 \mathrm{~F}, 11 \mathrm{G}$ \\
\hline 12 & storage & $12 \mathrm{~A}, 12 \mathrm{C}, 12 \mathrm{D}, 12 \mathrm{E}, 12 \mathrm{G}, 12 \mathrm{H}, 12 \mathrm{I}, 12 \mathrm{~J}, 12 \mathrm{~L}$ \\
\hline 13 & storage & $13 \mathrm{~A}, 13 \mathrm{~B}, 13 \mathrm{C}, 13 \mathrm{D}, 13 \mathrm{E}, 13 \mathrm{~F}, 13 \mathrm{G}, 13 \mathrm{H}, 13 \mathrm{I}$ \\
\hline 14 & storage & $14 \mathrm{~B}, 14 \mathrm{C} 1,14 \mathrm{C} 2,14 \mathrm{D}, 14 \mathrm{E} 1,14 \mathrm{~F}, 14 \mathrm{G}, 14 \mathrm{H}, 14 \mathrm{I}, 14 \mathrm{~J}, 14 \mathrm{M}, 14 \mathrm{~N}, 14 \mathrm{O}$ \\
\hline 15 & storage & $15 \mathrm{~A}, 15 \mathrm{~B} 1,15 \mathrm{~B} 2,15 \mathrm{C}, 15 \mathrm{D}, 15 \mathrm{E}, 15 \mathrm{~F} 1,15 \mathrm{~F} 2,15 \mathrm{G}, 15 \mathrm{H}, 15 \mathrm{I} 2,15 \mathrm{~J}$ \\
\hline 16 & storage & $16 \mathrm{~A}, 16 \mathrm{~B}, 16 \mathrm{C} 1,16 \mathrm{C} 2,16 \mathrm{D}, 16 \mathrm{E}, 16 \mathrm{~F}, 16 \mathrm{G}, 16 \mathrm{H}, 16 \mathrm{~J}, 16 \mathrm{~L}, 16 \mathrm{M}$ \\
\hline 17 & storage & $17 \mathrm{~A}, 17 \mathrm{~B}, 17 \mathrm{C}, 17 \mathrm{E}, 17 \mathrm{G}, 17 \mathrm{H}, 17 \mathrm{I}, 17 \mathrm{~J}$ \\
\hline 18 & storage & $18 \mathrm{~A} 1,18 \mathrm{~A} 2$ \\
\hline
\end{tabular}

Sci. Agric. (Piracicaba, Braz.), v.62, n.1, p.45-49, Jan./Feb. 2005 
cycle consisted of three steps: denaturation $\left(92^{\circ} \mathrm{C}, 40 \mathrm{~s}\right)$, annealing $\left(55^{\circ} \mathrm{C}, 1 \mathrm{~min}\right.$ and $\left.30 \mathrm{~s}\right)$ and elongation $\left(72^{\circ} \mathrm{C}\right.$, $2 \mathrm{~min}$ ). Final elongation at $72^{\circ} \mathrm{C}$ for $5 \mathrm{~min}$ was used. The amplified fragments were analyzed by gel electrophoresis in 1x TEB buffer according to Sambrook \& Russel (2001). The 1\% agarose gels were treated with ethidium bromide and the bands visualized under UV light.

Sequencing of the ITS region - The fragments of ITS15.8S-ITS2 amplified by PCR were sequenced according Sanger et al. (1977). The sequencing reaction was $10 \mu \mathrm{L}$, containing $2.0 \mu \mathrm{L}$ of ITS4 primer (Invitrogen$\left.3.0 \mu \mathrm{mL}^{-1}\right), 4.0 \mu \mathrm{L}$ of premix of DYEnamic ET terminator (Amersham Biosciences) and $4.0 \mu \mathrm{L}$ of the rDNA amplification product $\left(100 \mathrm{ng} \mu \mathrm{L}^{-1}\right)$. The reaction was submitted to a Mastercycler thermocycler gradient (Eppendorf), programmed to perform 35 cycles after initial denaturation $\left(95^{\circ} \mathrm{C}, 2 \mathrm{~min}\right)$. Each cycle consisted of three steps: denaturation $\left(95^{\circ} \mathrm{C}, 1 \mathrm{~min}\right)$, annealing $\left(55^{\circ} \mathrm{C}\right.$, $1 \mathrm{~min}$ ) and elongation $\left(60^{\circ} \mathrm{C}, 1 \mathrm{~min}\right)$. At the end of the cycles, there was a final elongation step $\left(60^{\circ} \mathrm{C}, 5 \mathrm{~min}\right)$. Sequencing was performed on a MegaBACE ${ }^{\mathrm{TM}} 1000$ sequencer (Amersham Biosciences). The conditions for injection and electrophoresis were $2 \mathrm{Kv} / 60 \mathrm{~s}$ and $6 \mathrm{Kv} / 230$ min, respectively.

Sequence analysis - The quality of the sequences was examined by Phred/Phrap/Consed package. For the identification of the isolates, the nucleotide sequences obtained were compared with those already deposited in the data bank of the National Center for Biotecnology and Information (NCBI), using BLAST search tool (Altschul et al., 1990). The identification of the species was determined based on the best score.

$A$. niger and $A$. tubingensis discrimination - The discrimination between the species $A$. niger and $A$. tubingensis was performed by RFLP analysis of rDNA in silico, by searching for the RsaI restriction site (GT/ $\mathrm{AC}$ at positions 295 and $303 \mathrm{bp}$ ) directly in the rDNA sequences of both species. The analysis was conducted with the aid of the programs Phred/Phrap/Consed and BioEdit (Hall, 1999).

\section{RESULTS AND DISCUSSION}

The amplification of the ITS1-5.8S-ITS2 region of rDNA for the 108 Aspergillus isolates, using the universal primers ITS 1 and ITS4 (White et al., 1990) originated a fragment of approximately $600 \mathrm{bp}$. This result is in accordance to the literature (Henry et al., 2000). These authors found ITS1-5.8S-ITS2 amplicons of sizes varying between 565 and 613 bp.

Analysis of the nucleotide sequences of the amplified fragments allowed the identification of the isolates at the species level (Table 2). The percentage of occurrence of each species among all Aspergillus identified is shown in Figure 1.

With the exception of $A$. tubingensis and $A$. carbonarius, the other species here identified have already been reported as contaminants of coffee samples from the state of Minas Gerais (Batista et al., 2003). According to these authors, among 155 isolates of Aspergillus identified by classical taxonomy, the species $A$. ochraceus, A. sulphureus, A. tamarii, A. niger and $A$.

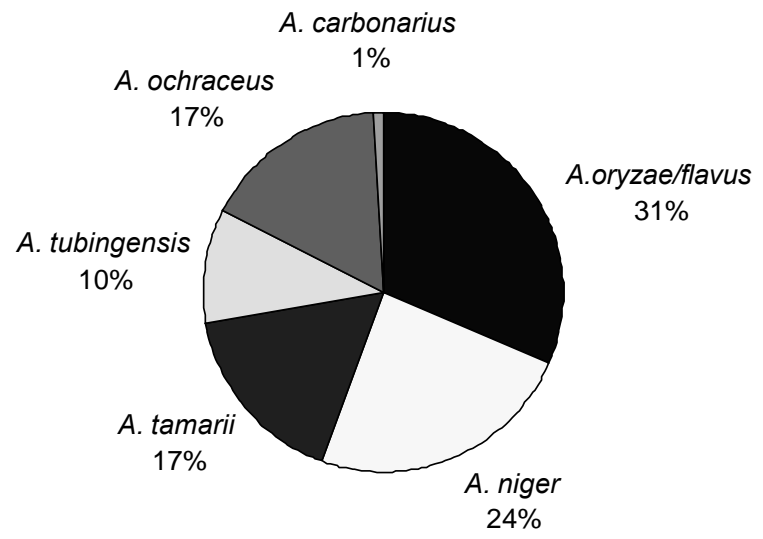

Figure 1 - Relative frequency of Aspergillus species in coffee bean samples.

Table 2 - Identification of Aspergillus species based on rDNA sequences.

\begin{tabular}{ll}
\hline Species & \multicolumn{1}{c}{ Isolate } \\
\hline \multirow{2}{*}{ A. flavus/oryzae (Section Flavi) } & A64, A92, A93, A132, A161, 4A, 4B, 11C, 11F, 12D, 12E, 12G, 12I, 13A, 13B, 13C, \\
& 17D, 14E1, 14H, 14I, 15A, 15B1, 15B2, 15C, 15D, 16E, 16F, 16J, 16L, 16M, 17A, \\
A. niger (Section Nigri) & A11, A51, A61, A62, A81, A103, A104, A162, 6A, 8A1, 8A2,11G,12C, 12L, 13E, \\
& 13F,13G, 13H, 14C2, 14M, 14N,15G, 16G, 16H, 17E, 17G \\
A. ochraceus (Section Circundati) & A13, A21, A65, A91, A101, A105, A131, A141, A151, A152, 12J, 14B, 14C1, 14D, \\
A. tubingensis (Section Nigri) & A12, A52, A102, 4E, 7A, 8B, 14F, 15F1, 16C1, 16D, 17H \\
A. tamarii (Section Flavi) & A63, 4C, 4D, 11B, 11D, 12A, 12H, 13I, 15E, 15F2, 15H, 15I2, 15J, 16A, 16B, 17I, \\
A. carbonarius (Section Nigri) & A71
\end{tabular}


flavus represented $71 \%$ of the isolates. Despite $A$. sulphureus has been frequently detected in coffee produced in Minas Gerais, this species was not found in coffee samples from Paraná.

The isolates belonging to the section Nigri were detected in $93.75 \%$ of the geographical regions and represented 35\% of the total Aspergillus spp. identified. Among the fungi of this section, $24 \%$ of the isolates were characterized as A. niger, $10 \%$ as A. tubingensis and $1 \%$ as $A$. carbonarius.

Currently, the presence of A. tubingensis in Brazilian coffee beans has not been described, probably because only classical taxonomy has been utilized, and it does not allow the discrimination of A. tubingensis from $A$. niger. These two species have a high morphological similarity and A. tubingensis was considered as a subspecies of $A$. niger. The utilization of molecular methods allowed a better distinction of the A. niger group until 1991 (Kusters-Van Someren et al., 1991; Varga et al., 1993; 1994; Accensi et al., 1999; 2001) and the classification of $A$. niger and A. tubingensis as distinct species.

In the present study, the distinction between $A$. niger and A. tubingensis was determined by RFLP analysis in silico. This analysis was based on the presence of the restriction site (at positions 295 and $303 \mathrm{bp}$ ) for the endonuclease $R s a \mathrm{I}$ (GT/AC) in ITS1 sequence from $A$. niger and its absence in A. tubingensis (Accensi et al., 1999). The correct discrimination between these species is relevant because $A$. niger has been reported as OA producer in coffee, while A. tubingensis is a non-producer species of this mycotoxin.

Varga et al. (2000) described that some nonochratoxigenic strains of $A$. niger has potential to decompose OA, through the secretion of a carboxypeptidase that converts OA to ochratoxin a and phenylalanine. Since $A$. tubingensis is unable to produce $\mathrm{OA}$ its potential to to control this mycotoxin in coffee should be addressed.

Of all the Aspergillus spp. identified, 48\% included the section Flavi represented by the species $A$. flavus/A. oryzae (31.5\%) and A. tamarii (16.5\%), which were detected in $75 \%$ of the geographical regions analyzed. Reports in the literature on the taxonomy of this section have been conflicting. According to Varga et al. (2003), the section Flavi includes the clades "A. flavus" and "A. tamarii," which includes respectively A. flavus/ oryzae and A. tamarii. The comparison between A. flavus and $A$. oryzae, based on molecular approaches, has demonstrated that they have high genetic similarity (Kurtzman et al., 1986; Chang et al., 1991; Nikkuni et al., 1996). Nikkuni et al. (1998) studied the nucleotide sequence of rDNA from Aspergillus spp. and showed that this methodology did not allow the discrimination of the species A. flavus and $A$. oryzae. Identical findings were observed in the present study by analyzing the ITS1, 5.8S and ITS2 rDNA regions.
Although A. oryzae and A. tamarii belong to distinct clades of the section Flavi, Nikkuni et al. (1998) showed that these species differ in a single nucleotide and three gaps in the alignment of the ITS sequences. Although some isolates belonging to species of the section Flavi have potential to produce mycotoxins in cereal grains, none of them produce OA in coffee beans (Varga et al., 2003).

The species $A$. ochraceus (section Circundati) was detected in $44 \%$ of the geographical regions. Approximately $17 \%$ of the isolates here identified belong to this species (Figure 1). This frequency is similar to that found by Batista et al. (2003) in coffee samples from Minas Gerais. According to Taniwaki et al. (2003), $75 \%$ of the isolates of $A$. ochraceus have potential for producing OA. Therefore, the presence of this species in coffee beans should be a warning for good practices for farming, particularly during drying and storage.

Aspergillus species that are potential producers of OA were found in $82 \%$ of the geographical regions examined. Among these, the species identified most frequently was $A$. niger, followed by $A$. ochraceus and $A$. carbonarius. An extensive study conducted by Taniwaki et al. (2003), in coffee beans (408 samples) from the states of São Paulo and Minas Gerais also showed A. niger as the most common species. Although A. niger was found at higher frequency than the other two species, only $3 \%$ of the isolates were capable of producing AO.

The A. carbonarius species is considered a potent producer of OA, since approximately $77 \%$ of its isolates are ochratoxigenic. Taniwaki et al. (2003) detected A. carbonarius in samples originated from drying and storage areas at São Paulo state. In the present study we demonstrated, for the first time, the presence of $A$. carbonarius in samples of fruit taken from trees. Recently, Fungaro et al. (2004) developed a specific marker for the detection of $A$. carbonarius in coffee beans. The use of this marker to determine the presence of this species in coffee beans is strongly recommended.

\section{ACKNOWLEDGMENTS}

This work was supported by grants and fellowships from Fundação Araucária, CNPq and CAPES. We thank Dr. Albert Leyva for his assistance in the preparation of the manuscript.

\section{REFERENCES}

ABARCA, M.L.; BRAGULAT, M.R.; CASTELLÁ, G.; CABAÑES, F.J. Ochratoxin A production by strains of Aspergillus niger var. niger. Applied and Environmental Microbiology, v.60, p.2650-2652, 1994.

ACCENSI, F.; CANO, J.; FIGUEIRA, L.; ABARCA, M.L.; CABAÑES, F.J. New PCR method to differentiate species in the Aspergillus niger aggregate. FEMS Microbiology Letters, v.180, p.191-196, 1999. 
ACCENSI, F.; ABARCA, M.L.; CANO, J.; FIGUEIRA, L.; CABAÑES, F.J. Distribution of ochratoxin A producing strains in the Aspergillus niger aggregate. Antonie van Leeuwenhoek, v.79, p.365-370, 2001.

ALTSCHUL, S.F.; GISH, W.; MILLER, W.; MYERS, E.W.; LIPMAN, D.J. Basic local alignment search tool. Journal of Molecular Biology, v.215, p.403-410, 1990.

AZEVEDO, A.C.S.; FURLANETO, M.C.; SOSA-GOMEZ, D.R.; FUNGARO, M.H.P. Molecular characterization of Paecilomyces fumosoroseus (Deuteromycotina: Hyphomycetes) isolates. Scientia Agricola, v.57, p.729-732, 2000.

BATISTA, L.R.; CHALFOUN, S.M.; PRADO, G.; SCHWAN, R.F.; WHEALS, A.E. Toxigenic fungi associated with processed (green) coffee beans (Coffea arabica L.). International Journal of Food Microbiology, v.85, p.239-300, 2003.

BUCHELI, P.; MEYER, I.; PITTET, A.; VUATAZ, G.; VIANI, R. Industrial storage of green Robusta coffee under tropical conditions and its impact on raw material quality and ochratoxin A content. Journal of Agricultural and Food Chemistry, v.46, p.4507-4511, 1998.

CHANG, J.M.; OYAIZU, H.; SUGIYAMA, J. Phylogenetic-relationships among eleven select species of Aspergillus and associated teleomorphic genera estimated from $18 \mathrm{~S}$ ribosomal-RNA partial sequences. Journal of General and Applied Microbiology, v.37, p.289-308, 1991.

FUNGARO, M.H.P.; VISSOTTO P.C.; SARTORI D.; VILAS-BOAS, L.A.; FURLANETO M.C.; TANIWAKI M.C. A molecular method for detection of Aspergillus carbonarius in coffee beans. Current Microbiology, v.49, p.121-125, 2004.

HALL, T.A. BioEdit: a user-friendly biological sequence alignment editor and analysis program for Windows 95/98/NT. Nucleic Acids Symposium, v.41, p.95-98, 1999.

HENRY, T.; IWEN, P.C.; HINRICHS, S.H. Identification of Aspergillus species using internal transcribed spacer regions 1 and 2. Journal of Clinical Microbiology, v.38, p.1510-1515, 2000.

KURTZMAN, C.P.; SMILEY, M.J.; ROBNETT, C.J.; WICKLOW, D.T. DNA relatedness among wild and domesticated species in Aspergillus flavus group. Mycologia, v.78, p.955-959, 1986.

KUSTERS-VAN SOMEREN, M.A.; SAMSON, R.A.; VISSER, J. The use of RFLP analysis in classification of the black Aspergilli: reinterpretation of the Aspergillus niger aggregate. Current Genetics, v.19, p.21-26, 1991.

LEVI, C.P.; TRENK, H.L.; MOHR, H.K. Study of the occurrence of ochratoxin A in green coffee beans. Journal of the AOAC International, v.57, p.866-870, 1974.

MOSS, M.O. Mode of formation of ochratoxin A. Food Additives and Contaminants, v.13, p.5-9, 1996.

MULLIS, K.B.; FALOONA, F.A. Specific synthesis of DNA in vitro via a polymerase catalysed chain reaction. Methods in Enzymology, v.155, p.335-350, 1987.

NEERGARD, P. Seed pathology. London: McMirlan, 1979. v.1, p.739754.
NIKKUNI, S.; KOSAKA, N.; SUZUKI, C.; MORI, K. Comparative sequence analisys on the 18S rRNA gene of Aspergillus oryzae, A. sojae, A. flavus, A. parasiticus, A. niger, A. awamori and A. tamarii. Journal of General and Applied Microbiology, v.42, p.181-187, 1996.

NIKKUNI, S.; NAKAJIMA, H.; HOSHINA, S.; OHNO, M.; SUZUKI, C.; KASHIWAGI, Y.; MORI, K. Evolutionary relationships among Aspergillus oryzae and related species based on the sequences of $18 \mathrm{~S}$ rRNA genes and internal transcribed spacers. Journal of General and Applied Microbiology, v.44, p.225-230, 1998.

PITT, J.I.; HOCKING, A.D. Fungi and food spoilage. 2.ed. Cambridge: Champman \& Hall, 1997.

PONTECORVO, G.; ROPER, J.A.; HEMMONS, L.M.; MACDONALD, K.D.; BUFTON, A.W.J. The genetics of Aspergillus nidulans. Advances in Genetics, v.5, p.141-148, 1953.

SAMBROOK, J.; RUSSEL, D.W. Molecular cloning. A laboratory manual. 3.ed. New York: Cold Spring Harbor Laboratory Press, 2001.

SANGER, F.; NICKLEN, S.; COULSON, A.R. DNA sequencing with chain - terminating inhibitors. Proceedings of the National Academy of Sciences of the USA, v.74, p.5463-5467, 1977.

TANIWAKI, M.H.; PITT, J.I.; TEIXEIRA, A.A.; IAMANAKA, B.T. The source of ochratoxin A in Brazilian coffee and its formation in relation to processing methods. International Journal of Food Microbiology, v.82, p.173-179, 2003.

VARGA, J.; KEVEI, F.; FEKETE, C.; COENEN, A.; KOZAKIEWICZ, Z.; CROFT, J.H.; Restriction fragment length polymorphisms in the mitochondrial DNAs of the Aspergillus niger aggregate. Mycological Research, v.97, p.1207-1212, 1993.

VARGA, J.; KEVEI, F.; VRIESEMA, A.; DEBETS, F.; KOZAKIEWICZ, Z.; CROFT, J.H. Mitochondrial DNA restriction fragment length polymorphisms in field isolates of the Aspergillus niger aggregate. Canadian Journal of Microbiology, v.40, p.612-621, 1994.

VARGA, J.; RIGÓ, K.; TÉREN, J. Degradation of ochratoxin A by Aspergillus species. International Journal of Food Microbiology, v.59, p.1-7, 2000.

VARGA, J.; RIGÓ, K.; TÓTH, B.; TÉREN, J.; KOZAKIEWICZ, Z. Evolutionary relationships among Aspergillus species producing economically important mycotoxins. Food Technology and Biotechnology, v.41, p.29-36, 2003.

WHITE, T.J.; BRUNS, T.; LEE, S.; TAYLOR, J. Amplification and direct sequencing of fungal ribosomal RNA genes for phylogenetics. In: INNIS, M.A.; GELFAND, D.H.; SNINSKY, J.J.; WHITE, T.J. (Ed.) PCR protocols: A guide to methods and applications. San Diego: Academic Press, 1990. p.315-322.

$\overline{\text { Received May 05, }} 2004$

Accepted September 13, 2004 